\title{
TWO NEW ANTS COLLECTED IN QUARANTINE
}

\author{
By W. M. MANN
}

National Zoological Park, Washington, D. C.

The writer has for some years had the privilege of seeing and identifying the ants collected at the various quarantine stations of the United States Government. These are intercepted from all parts of the world, and during the course of years a great many species have been received. There is of course a preponderance of certain common tropical species, but occasionally great rarities come in.

During the past year two most interesting species have been sent from the station at Honolulu, one a Macromischa, the other a second species of the genus Zatapinoma, both of which seem worth while recording here.

\section{Macromischa luciliæ n. sp.}

Worker (Fig. 1)

Length $2.75 \mathrm{~mm}$.

Head a little longer than broad, slightly narrower in front than behind, with moderately convex sides, broadly rounded occipital corners and nearly straight borders. Clypeus, convex, truncate in front; frontal area large and strongly impressed. Eyes convex, situated slightly in front of middle side of head. Antennal scapes barely surpassing occipital corners; first funicular joint as long as the two following joints together; joints 2-9 sub-equal in length, slightly broader than long; club elongate; the terminal joint as long as the two preceding joints together. Thorax in profile very arcuate, without distinct sutures; epinotal spines stout, nearly straight, as long as the epinotal declivity. Postpetiole long and slender; the peduncle twice as long as the node, which rises abruptly and is higher than long and from above broader than the node and $11 / 2$ times as broad as long. Femora, especially posterior pair, thickened.

Head and thorax closely punctate and sublucid, the thorax and epinotum more closely than the head; petiole, post- 
petiole and gaster shining; legs finely and densely punctate and shining. Hair moderately abundant on head, thorax and abdomen, erect and very coarse, whitish in color.

Color piceous except the anterior half of the epinotal spines which are ivory white; legs and antennæ somewhat lighter.

Described from a small series of workers taken in quarantine at Honolulu on roots of Oncidium splendidum, from Guatemala.

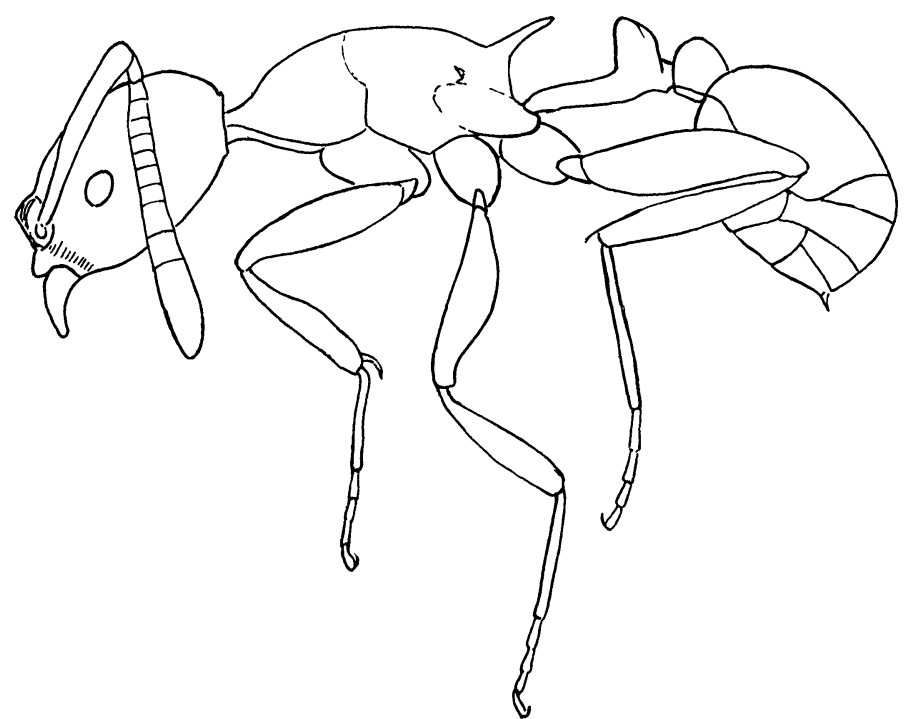

FIg. 1. Macromischa luciliae sp. nov. Worker. Profile view.

A very distinct species, superficially resembling albaspina from Mono Island, but much larger, more shining and with entirely different petiole.

Co-types No. 50802, U. S. National Museum.

\section{Zatapinoma wheeleri $\mathrm{n}$. sp.}

Length $2.75 \mathrm{~mm}$.

Soldier (Fig. 2)

Head nearly twice as long as broad and broader in front than behind, with straight parallel sides, broadly rounded occipital corners and very shallowly concave borders. Eyes elongate, very slightly convex with nine facets in their greatest longitudinal diameter. Mandibles large and thick, 
their inner blades with five coarse teeth. Clypeus nearly straight at anterior border; surface at sides with two strong nearly parallel carinæ, the surface moderately convex. Funicular scapes extending about $5 / 8$ the distance to occipital corners, slightly thickened apically; funiculi moderately enlarged toward the tip, the first joint longer than the second and third together; joints 2-10 broader than long; terminal joint longer than the two preceding joints together. Thorax robust, pronotum more than twice as broad as long, broader in front than behind and with nearly straight sides; mesonotum from above $1 \frac{1}{2}$ times as long as

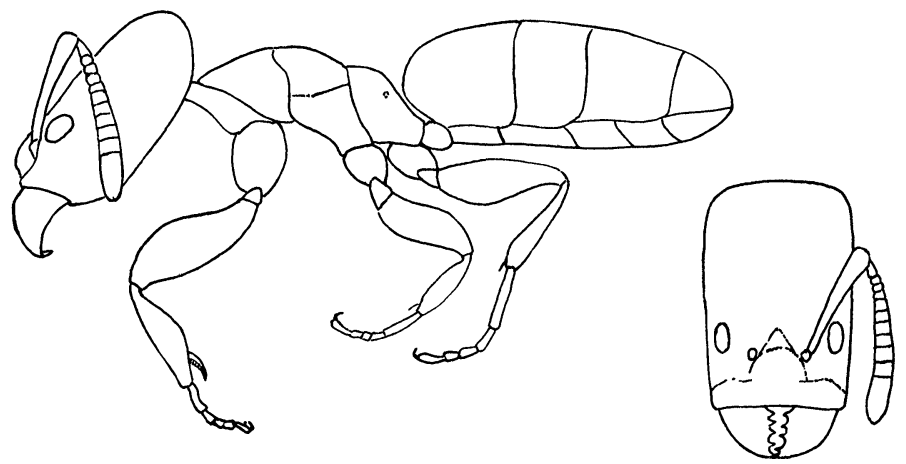

FIG. 2. Zatapinoma wheeleri sp. nov. Worker. Profile view and dorsal view of head.

pronotum, narrowed posteriorly; mesoepinotal suture very distinct; epinotum a little longer than broad in profile, with convex base and declivity; petiole sub-rectangular.

Moderately shining except mandibles and clypeus which are shallowly but densely punctate and opaque, the remainder smooth. Hairs very sparse, pubescence very fine and short, yellow' in color, both abundant on head.

Color pale yellowish brown.

Described from three soldiers taken in quarantine at Honolulu on plants from Samoa.

Co-types No. 50801, U. S. National Museum.

The only other described species, $Z$. annandale $i$, recently described from India by Wheeler, differs in having the head broader, the mandibular teeth smaller and more numerous, and the clypeal area darker than the rest of head. 

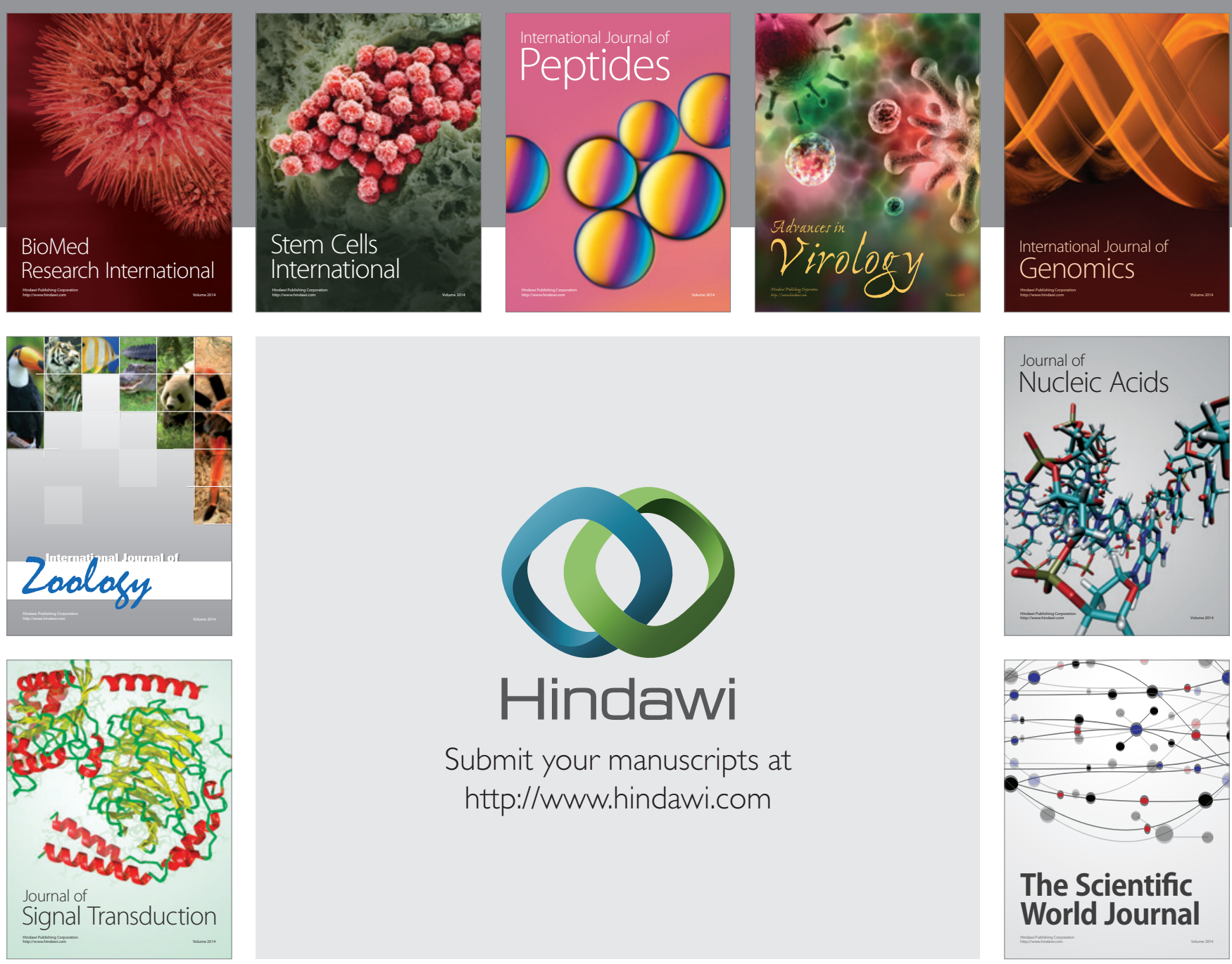

Submit your manuscripts at

http://www.hindawi.com
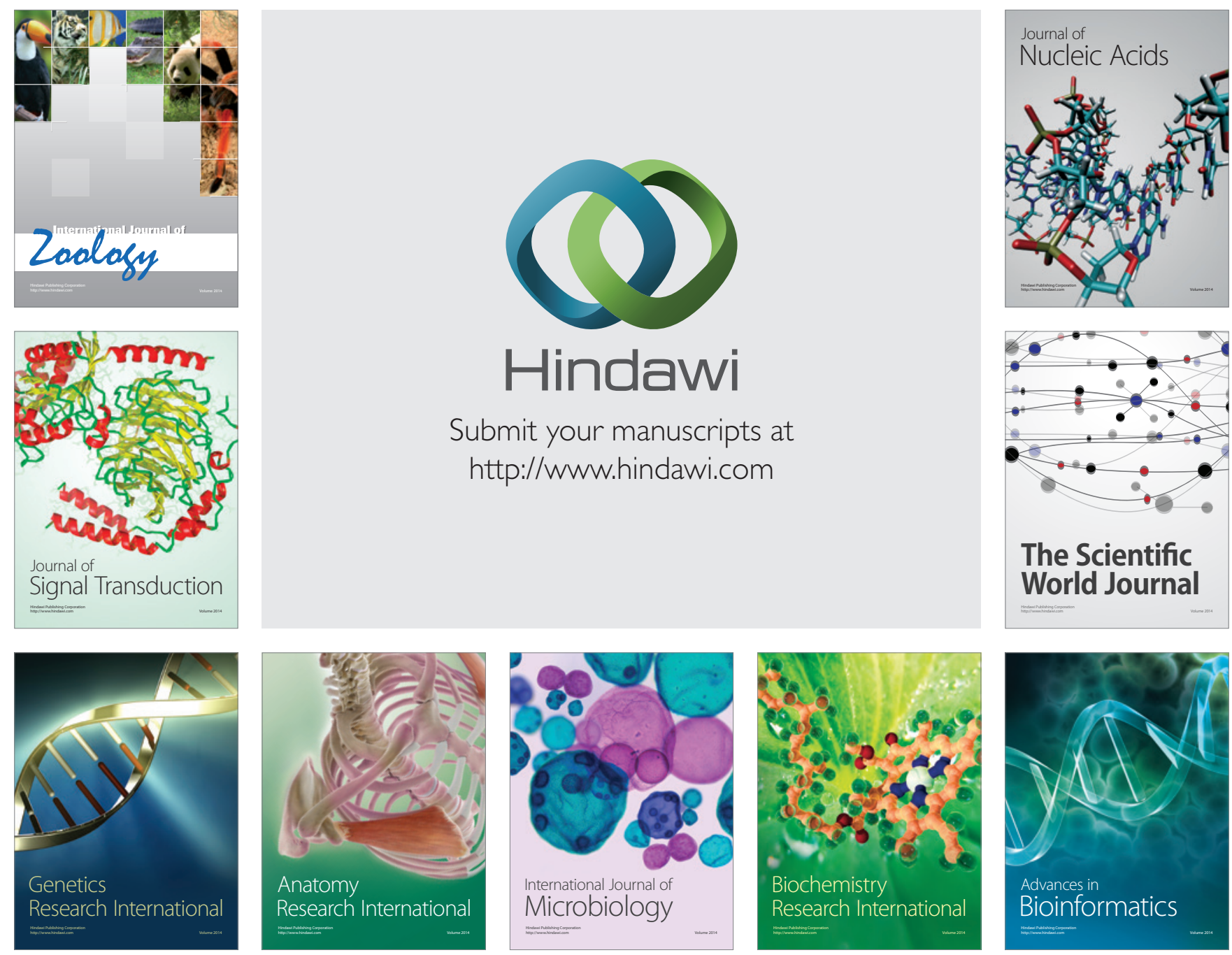

The Scientific World Journal
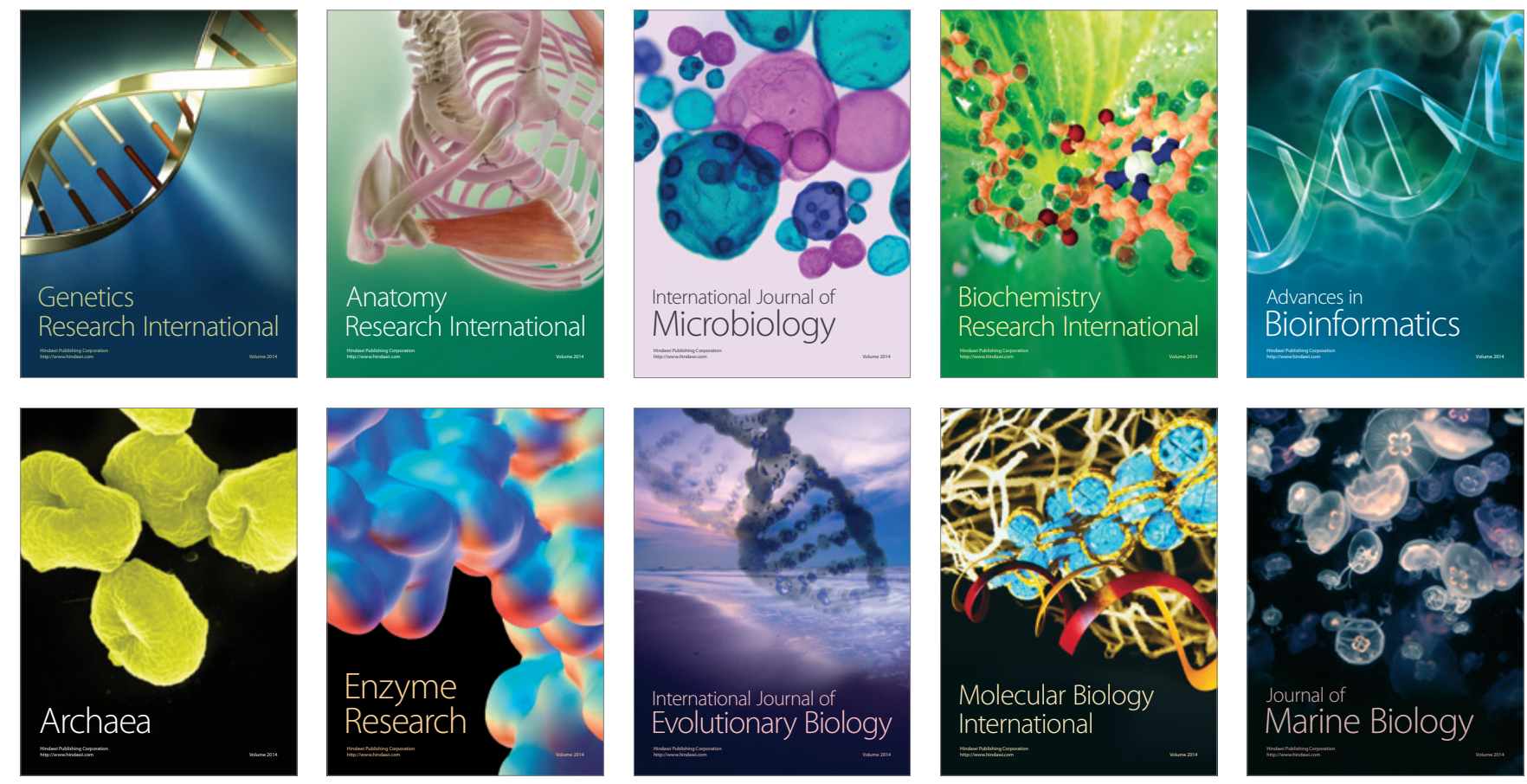